\title{
Ruang Belajar Online Sebagai Implementasi Pembelajaran Daring Pada Murid Sekolah Dasar Muhammadiyah 22 Meranjat
}

\author{
Muhamad Tian' ${ }^{1}$, Christofora Desi $K^{2}$, Septa Hardini ${ }^{3}$ Poppy Indriani ${ }^{4}$ \\ Teknik Industri, Universitas Bina Darma ${ }^{1,2,3}$ \\ Akuntansi, Universitas Bina Darma ${ }^{4}$ \\ Email: desi_christofora@binadarma.ac.id, Septa@binadarma.ac.id, \\ poppy.indriani@binadarma.ac.id
}

\begin{abstract}
ABSTRAK
Pembelajaran daring dengan menggunakan berbagai macam aplikasi pembelajaran merupakan inovasi pendidikan untuk menjawab tantangan akan ketersediaan sumber belajar yang variatif. Keberhasilan dari suatu model ataupun media pembelajaran tergantung dari karakteristik peserta didiknya. Sebagai mana yang literatur dalam e-learning mengindikasikan bahwa tidak semua peserta didik akan sukses dalam pembelajaran online. Ini dikarenakan faktor lingkungan belajar dan karakteristik peserta didik. Sehinga adanya kegiatan yang dapat membantu dalam hal pembelajaran daring anak sekolah dasar Muhammadiyah 22 Meranjat akibat dari adanya pandemik COVID-19. Tujuan yang ingin dicapai yaitu membantu penerapan pembelajaran daring siswa sekolah dasar ditengah wabah covid -19. Metode pengembangan dari PKM-M yang akan dilaksanakan merupakan sebuah rangkaian tahapan yang disusun secara sistematis, berikut adalah gambaran flow map. Hasil yang di Capai yaitu Sebagai Ruang Pembelajaran Daring, membantu orang tua dalam mengajari anaknya, Membantu Murid dalam memahami pelajaran. Sehingga aspek ekonomi murid tidak perlu datang ke sekolah dan bisa menabung uang jajan mereka untuk membeli kuota internet. Aspek kesehatan dengan pembelajaran online murid menghindari Resiko terdampak covid-19 dengan tidak bertemu langsung dengan orang lain.
\end{abstract}

Kata kunci : Manusia, Pembelajaran Daring, Internet

\begin{abstract}
Online learning using a variety of learning applications is an educational innovation to answer the challenges of the availability of varied learning resources. The success of a model or learning media depends on the characteristics of the students. As the literature in e-learning indicates that not all students will be successful in online learning. This is due to the learning environment factors and the characteristics of students. So that there are activities that can help in terms of online learning of 22 Meranjat Muhammadiyah elementary school children due to the COVID-19 pandemic. The objectives to be achieved are assisting the application of online learning for elementary school students in the midst of the covid -19 outbreak. The development method of PKM-M to be implemented is a series of stages arranged systematically, the following is an overview of the flow map. The results achieved are as an online learning space, helping parents in teaching their children, helping students in understanding lessons. So that the economic aspect of students does not need to come to school and can save their pocket money to buy internet quotas. The health aspect of online learning students avoids the risk of being affected by covid-19 by not meeting other people directly.
\end{abstract}

Keywords: Human, Online Learning, Internet 


\section{PENDAHULUAN}

Di perujung tahun 2019 kita sebagai umat manusia di kejutkan dengan datanngnya wabah atau penyakit yang di sebut dengan pneumonia atau corona virus disease, wabah ini berasal dari wuhan china.

WHO telah menetapan kedaruratan kesehatan masyarakat pada tanggal 30 januari 2020, Indonesia melaporkan kasus konfirmasi dan Kebudayaan Republik Indonesia mengeluarkan Surat Edaran Nomor 4 Tahun 2020 Tentang Pelaksanaan Kebijakan Pendidikan Dalam Masa Darurat Penyebaran Covid, dalam Surat Edaran tersebut dijelaskan bahwa proses belajar dilaksanakan di rumah melalui pembelajaran daring/jarak jauh dilaksanakan untuk memberikan pengalaman belajar yang bermakna bagi siswa. Belajar di rumah dapat difokuskan pada pendidikan kecakapan hidup antara lain mengenai pandemi Covid-19 (Dewi, 2020:56)

Supaya mengurangi dampak dari wabah ini . Menteri Pendidikan dan Kebudayaan (Mendikbud) menindak lanjuti kebijakan tersebut melalui Surat Edaran (SE) Nomor, 4 Tahun 2020 Tentang Pelaksanaan Kebijakan Pendidikan Dalam Masa Darurat Penyebaran Covid-19, dalam hal ini poin 2 yang menyatakan, proses Belajar dari Rumah dilaksanakan dengan ketentuan sebagai berikut (Pakpahan \& Fitriani, 2020:31):

a) Pembelajar dari rumah atau daring, sebagai metode yang dilakukan agar dapat mengurangi penyebaran wabah penyakit ini

b) Pembelajar dari Rumah dapat difokuskan agar dapat memberikan pengetahuan yang lebih efektif di tengah wabah covid-19

c) Pemberian tugas secara daring harus mempertimbangkan kesesuaian atau minat dan kondisi bagi para murid.

Akibat dari wabah Covid-19 ini, semua aktivitas dilakukan di rumah, karena apabila kita melanggar protokol kebijkan pemerintah akan berakibat membahayakan bagi diri sendiri, sehingga dalam hal pendidikan juga terkena imbasnya karena aktivitas yang awalnya dilakukan tatap muka dilakukan di sekolah dengan guru selama kegiatan belajar mengajar, sekarang berubah menjadi pembelajaran daring, dengan hal ini membuat anak merasa banyak kesulitan karena tidak semua materi pelajaran bisa tersapaikan dengan baik, karena kendala sinyal ataupun alat komunikas. Oleh karena itu untuk memudahkan murid-murid sekolah dasar dalam belajar di rumah, diperlukan suatu komunikasi yang baik. 
Pembelajaran yang diterapkan pada sekolah dasar juga menggunakan pembelajaran daring/jarak jauh dengan melalui bimbingan . Menurut Isman pembelajaran daring merupakan pemanfaatan jaringan internet dalam proses pembelajaran. Pembelajaran daring siswa memiliki keleluasaan waktu belajar, dapat belajar kapanpun dan dimanapun. Siswa dapat berinteraksi dengan guru menggunakan beberapa aplikasi seperti classroom, video converence, telepon atau live chat, zoom maupun melalui whatsapp group (Nakayama $\mathrm{M}$, Yamamoto H, 2007).

Berdasarkan observasi di lapangan, di Desa Meranjat ini banyaknya keluhan dari orang tua akibat pembelajaran daring yang belum optimal di karenakan pembelajarannya masih menggunakan WhatsApp dan belum ada grub yang bisa membahas bersama oleh karena itu banyak orang tua merasakan kesulitan dalm mengajari anak ketika ada tugas, serta anak-anak juga kebingungan karena bagi murid sekolah dasar dalam pembelajaran daring sangat memerlukan peran orang tua, karena guru hanya sebagai fasilitator tidak bisa mengontrol kegiatan belajar anak ketika dalam pembelajaran daring. Masa Darurat Penyebaran Covid, sungguh sangat berimbas pada ekonomi, sosial, pariwisata, bahkan dunia pendidikan, banyak anak-ank sekolah merasa kebingungan dalam belajar, karena kegiatan belajar mengajar dilakukan secara daring.

Oleh karena itu perlu di buat WhatsApp group yang bertujuan untuk membantu murid dan orang tua murid dalam memahami pembelajaran yang guru berikan.Pembelajaran daring dengan menggunakan berbagai macam aplikasi pembelajaran merupakan inovasi pendidikan untuk menjawab tantangan akan ketersediaan sumber belajar yang variatif. Keberhasilan dari suatu model ataupun media pembelajaran tergantung dari karakteristik peserta didiknya. Sebagai mana yang diungkapkan oleh Nakayama bahwa dari semua literatur dalam e-learning mengindikasikan bahwa tidak semua peserta didik akan sukses dalam pembelajaran online. Ini dikarenakan faktor lingkungan belajar dan karakteristik peserta didik. (Nakayama M, Yamamoto H, 2007). Tujuan yang ingin di capai dari pengabdian ini adalah membantu penerapan pembelajaran daring siswa sekolah dasar ditengah wabah covid -19 .

Monografi Desa Meranjat Tahun 2018.Desa Meranjat merupakan salah satu desa yang terdapat di kecamatan Indralaya Selatan. Desa Meranjat yang pada awalnya merupakan suatu warga yang mempunyai sejarah perkembangan sendiri sehingga menjadi sebuah desa. Desa Meranjat merupakan salah satu dari 14 Desa di Wilayah Kecamatan Indralaya Selatan yang terletak $2 \mathrm{~km}$ dari Kecamatan Indralaya Selatan. Desa Meranjat terdiri dari 2 Dusun yaitu Dusun I dan Dusun 2 dan masing-masing dusun terdapat 2 RT. 
Desa Meranjat merupakan daerah dataran rendah dengan kondisi wilayah terdiri dari tanah persawahan, daerah pemukiman, ladang, dan lebak rawa dengan batas-batas wilayah sebagai berikut: "Sebelah Utara berbatasan dengan Desa Beti, sebelah Selatan berbatasan dengan Desa Meranjat I, sebelah Timur berbatasan dengan Desa Tanjung Dayang Selatan, sebelah Barat berbatasan dengan Sejaro Sakti". Warga masyarakat Desa Meranjat bermata pencarian Petani, Pedagang dan PNS. Fasilatas Sekolah yang ada di Desa Meranjat dari SD 1 Indaralaya Selatan, Sd Muhammadiyah 22 Meranjat, SMP Muhammadiyah, SD 14 Indralaya Selatan, TK Aisyiyah, TK Nurul Hasanah, SMP Negeri 1 Indralaya Selatan dan SMK Negeri 1 Indralaya Selatan (Data Monogtafi Desa Meranjat). Pada penelitian ini fokus yang objek dan subjek yang dikaji pada SD Muhammadiyah 22 Meranjat, pada murid Sekolah Dasar Kelas 4, 5 dan 6 (Arsip Monografi Desa Meranjat: 2018).

Sekolah Dasar Muhamadiyah 22 Meranjat terletak di dusun meranjat, Kecamatan Indralaya Selatan, Kabupaten Ogan Ilir, Provinsi Sumatera Selatan. SD Muhammadiyah ini dikenal masyarakat desa meranjat sebagai sekolah yang mengajarkan keagamaan islam yang baik di desanya. Namun, aktivitas-aktivitas atau ritual-ritual keagamaan tidak hanya ilu agama yang di menjadi tolak ukur pemgajaran tetapi ilmu dibidang akademik juga sangat diunggulkan, sehingga dalam hal keagamaan terlihat begitu semarak serta kesadaran dari kepala keluarga dan warga dalam membekali putra-putri menuntut ilmu untuk bersekolah di lembaga formal juga non formal. Hal ini ditandai dengan begitu banyaknya rutinitas kegiatan keagamaan seperti (Arsip Data Sekolah: 2019):

1) Mengaji (Membaca surah pendek ) yang dilakukan para anak-anak sekolah pada saat setiap hari Kamis.

2) Kegiatan sholat dzuhur berjamaah pada setiap hari kamis supaya para siswa terbiasa dalam melakukan kewajibannya sebagai umat islam.

3) pembersihan setiap harinya demi menjaga kebersihan lingkungan sekolah. SD Muhammadiyah memiliki Luas tanah $3310 \mathrm{~m}$ dan luas bangunan $160 \mathrm{~m}$ dan hak kepemilikan yayasan muhammadiyah.

Jumlah Guru yang mengajar di SD Muhammadiyah 22 Meranjat terdiri atas 1 orang kepala sekolah, 9 Orang guru kelas, 1 orang guru agama, 1 orang guru operator sekolah, dan 1 orang kepustakaan . 
Tabel 1 Data Murid SD muhamadyah 3 tahun terakhir

\begin{tabular}{|c|c|c|c|c|c|c|}
\hline \multirow{2}{*}{ Kelas } & \multicolumn{2}{|c|}{2017} & \multicolumn{2}{c|}{2018} & \multicolumn{2}{c|}{2019} \\
\cline { 2 - 7 } & Putra & Putri & Putra & Putri & Putra & Putri \\
\hline 1 & 15 & 14 & 14 & 24 & 14 & 10 \\
\hline 2 & 26 & 19 & 14 & 15 & 14 & 26 \\
\hline 3 & 16 & 24 & 29 & 19 & 13 & 14 \\
\hline 4 & 20 & 15 & 22 & 22 & 29 & 18 \\
\hline 5 & 22 & 22 & 20 & 16 & 17 & 24 \\
\hline 6. & 17 & 22 & 22 & 21 & 20 & 16 \\
\hline TOTAL & 116 & 116 & 121 & 117 & 107 & 108 \\
\hline
\end{tabular}

Sumber : Data Sekolah

\section{METODE}

Untuk gambaran tata pelaksanaan program yang akan dilaksanakan setelah menentukan daerah sasaran yang akan menjadi tempat pelaksanaan program adalah sebagi berikut, langkah awal yang akan diterapkan adalah meminta izin kepada pihak yang bersangkutan untuk melaksanakan kegiatan di daerah sasaran. Langkah selanjutnyamenyampaikan sosialisasi, karena pandemic Covid-19 maka sosialisasi dilakukan dengan beberapa orang saja dan selebihnya dilakukan melaui daring, serta pembelian dan persiapan peralatan yang dibutuhkan untuk menunjang pelaksanaan kegiatan. Langkah Selanjutnya membuat dan mempersiapkan contoh dari bentuk kegiatan yang akan dijalankan. Langkah selanjutnya pengondisian Mitra yang telah setuju untuk melakukan kerja sama. Langkah selanjutnya atau langkah akhir sosialisasi program terhadap masyarakat sekitar. Bentuk kegiatan yang akan dilakukan akan berfokus pada usaha pebelajaran daring bagi siswa sekolah dasar, karena bertujuan untuk mengurangi beban orang tua dan memberikan wawasan kepada siswa bahwa pandemic Covid-19 ini bukanlah ajang untuk bersantai-santai dan berlibur tetapi harus melalui produktif dengan kegiatan pemebalajaran secara darang, dan apabila siswa sekolah dasar tersebut mengalami kesulitan dalam mengerjakan tugas bisa menanyakan dan bisa bediskusi dengan group dengan daring seperti Whattsapp groupmaupun aplikasi lainnya.

Beberapa usaha yang dilakukan untuk merealisasikan hal tersebut. kegiatan yang akan dilakukan diantaranya :

1. Sosialisasi kepada orang tua murid Sekolah Dasar

Kegiatan ini dilakukan untuk mempermudahkan murid Sekolah Dasar fokus pada murid kelas 4 dalam pembelajaran daring. 
2. Pencarian jejaring sosial

Kegiatan ini bertujuan mengumpulkan kontak person orang tua atau Sekolah Dasar, terkait pembelajaran daring.

3. Pebuatan media pembelajaran daring

Pembuatan media pembelajaran daring, dengan mempergunakan media whatsapp group.

4. Pelaksanaan pembelajaran daring

Kegiatan ini, bertujuan untuk membantu murid-murid Sekolah Dasar dalam kegiatan belajar mengajar, serta membantu meringankan beban orang tua selama di tengah pandemic Covid-19.

Metode pengabdian yang akan di terapkan adalah secara sistematis dengan menggunakan gambaranflow map yang telah disusun :

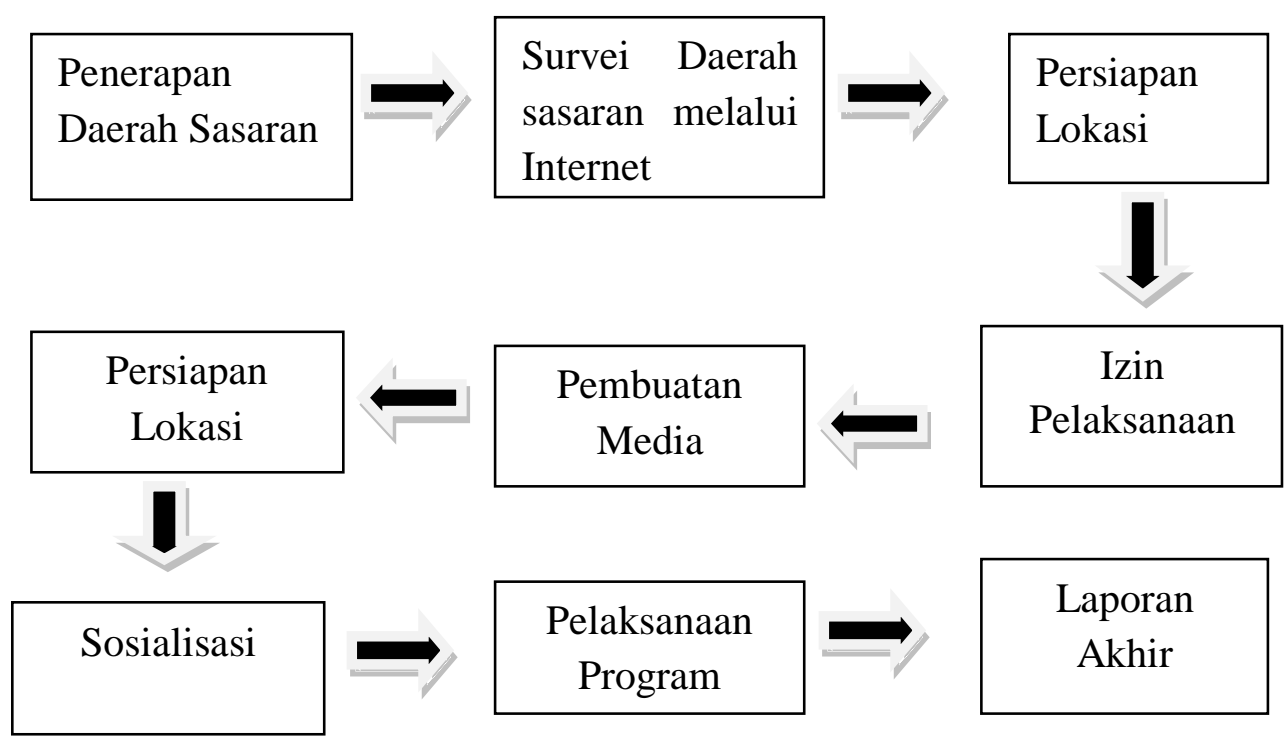

Gambar 3.1 Tahapan Pelaksanaan

Definisi dari flow map di atas :

1. Menetapankan daerah sasaran untuk pelaksanaan program

2. Meninjau beberapa lokasi

3. Melakukan pengamatan terhadap lingkungan masyarakat

4. Izin pelaksanaan untuk pelaksanaan kegiatan

5. Pembuatan media sebagai upaya persiapan pelaksanaan program

6. Persiapan lokasi untuk memulai kegiatan

7. Sosialisasi pada mitra dan masyarakat yang akan diikutkan dalam program

8. Pelaksanaan program yang telah direncanakan

9. Laporan akhir. 


\section{HASIL PEMBAHASAN, DAN DAMPAK}

A. Hasil yang di Capai

Hasil yang di capai dari hasil pelaksanaan program kreativitas mahasiswa dalam kegiatan PKM-M adalah seebagai berikut :

\section{1). Sebagai Ruang Pembelajaran Daring}

Ruang belajar ini merupakan ruang belajar online yang menggunakan aplikasi WhatsAppGroup merupakan salah satu Ruang belajar pada kondisi pandemik COVID19 sekarang ini dengans emua aktivias terkhusus bidang pendidikan dilakukan secara daring di rumah. Sehingga ruang belajarang daring dengan aplikasi WhatsAppGroup bertujuan untuk mengimplementasikan ruang belajar daring dalam membantu murid ketika mengalami kesulitan dalam memahami pelajaran dan menjelaskan kembali materi pelajaran ataupun tugas yang di berikan oleh guru.

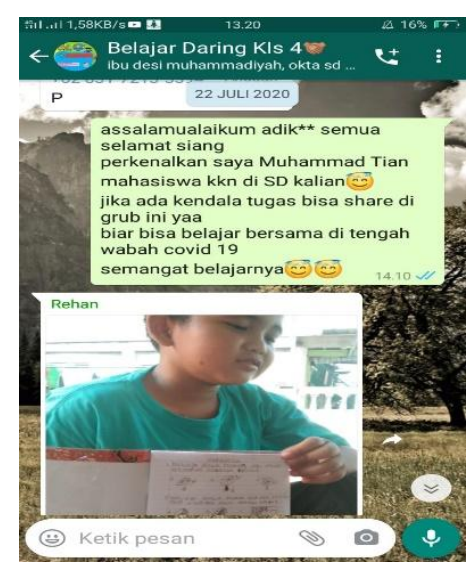

Gambar 1 Perkenalan grup Pembelajaran daring

2). Membantu Orang Tua mengajari anaknya

Membantu Para Orang tua wali Murid dalam mengajarkan anak -anaknya dalam menyelesaikan tugas yang di berikan oleh guru secara online. Berdasarkan pengamatan peneliti banyak orang tua yang menjerit ketika dihadapkan dengan situasi sekarang akibat pandemik COVID-19. 


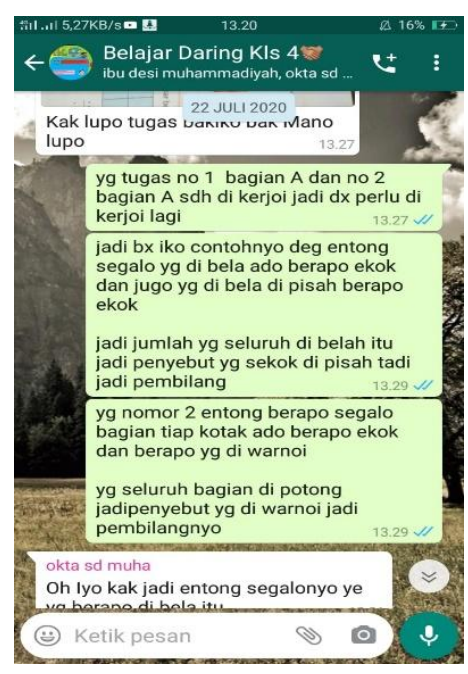

Gambar 2. Pemberian pemahaman terkait materi pelajaran

\section{3). Membantu Murid}

Dalam menyelesaikan tugas sekolah membuat murid lebih menyenangkan belajar bersama di grub online di tengah wabah covid-19 dan juga membantu murid yang tidak mempunyai android hal ini saya berinsiatif untuk mendatangi langsung ke rumah murid tersebut. Pada pemahaman murid terkait materi pelajaran yang disampaikan oleh guru, terkadang murid sulit untuk memahami karena tidak secara langsung guru menjelaskan materi pelajaran, terkadang murid lupa waktu untuk belajar karena terlalu banyak bermain di rumah, dan murid terkadang tidak ada motivasi untuk mengerjakan tugas yang diberikan oleh guru, karena materi pelajaran yang diberikan oleh guru tidak disampaikan secara maksimal sehingga banyak murid yang tidak memahami terkait materi pelajaran yang diberikan oleh guru.

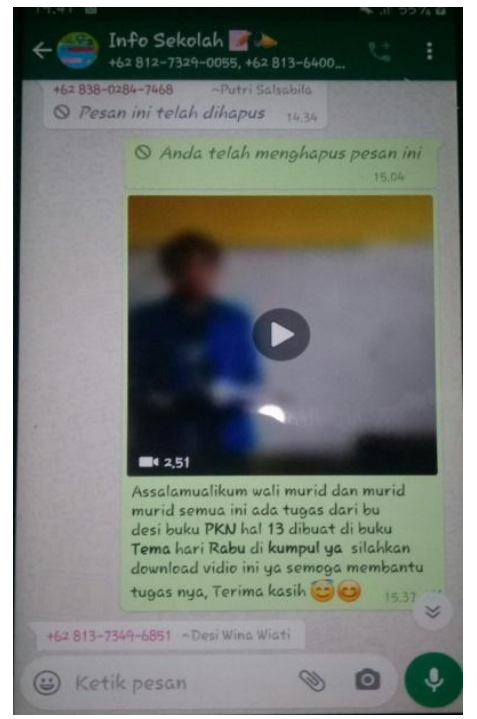

Gambar 3. Penjelasan Tugas kepada murid 


\section{4). Dorongan Motivasi}

Tidak hanya membantu dalam menjelaskan tugas yang di berikan guru tetapi disini juga memberikan motivasi kepada murid agar terus bersemangat dalam menyelesaikan tugas sekolah yang di berikan oleh guru,n sehingga pada saat pandemik COVID-19 ini dorongan dan motivasi selalu jadi nomer 1, karena murid harus tetap belajar dan mengerjakan tugas meskipun di rumah, dengan aplikasi dari pembelajaran daring, tetapi banyak kendala dan kesulitan dari olah data peneliti seperti kuota, HP Android yang tidak ada, serta murid sulit memahami materi pelajaran yang diberikan guru, karena terkadang penjelasan guru sangat terbatas dan tidak bisa bertanya secara langsung kepada guru.

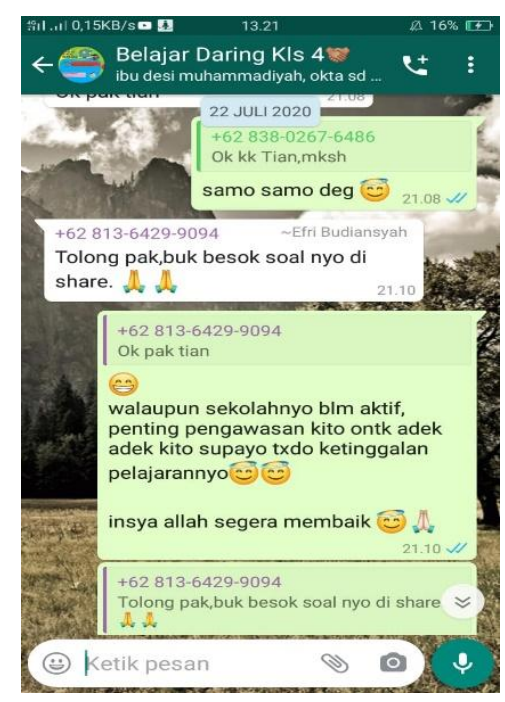

Gambar 4. Pemberian Motivasi kepada murid

Dibawah ini adalah ketercapaian hasil ditinjau dari analisis flow map yang akan berjalan

B. Dampak dari Pengabdian

1). Penerapan Daerah Sasaran

Survey lapangan ke SD Muhammadiyah secara langsung, hal ini di maksudkan agar mengetahui bagaimana situasi pembelajaran di lakukan di tempat mitra, peninjauan ini di bantu langsung oleh kepala sekolah dan wali kelas IV di mana mereka meminta izin kepada orang tua murid datang ke sekolah dan bisa mendengarkan keluhan dari mereka terkait proses belajar mengajar, tetapi hal ini cman setengah murid yang bisa datang ke sekolah dan bisa di katakan sebanyak 50\% 


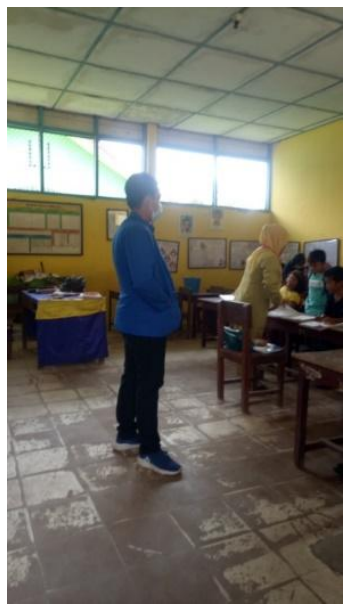

Gambar 5 Penerapan Daerah Sasaran

\section{2). Pembuatan Media WhatsApp Group}

Mahasiswa membuat WhatsApp Group sebagai Ruang Belajar Online dimana Ruang belajar ini difungsikan sebagai media pembelajaran dan diskusi bserta mengajarui pahaman tugas yang di berikan oleh Guru, Pembuatan WhatsApp Group ini sedikit mengalami kendala di karenakan ada murid yang belum mempunyai android

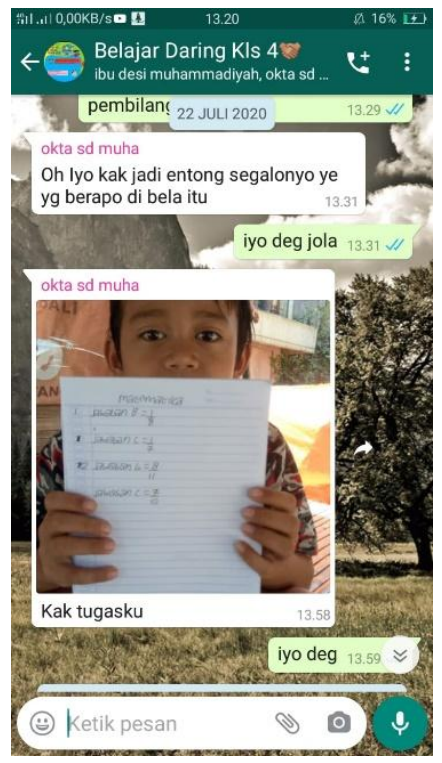

Gambar 6 Media Pembelajaran

\section{3). Sosialisasi}

Selain sosialisasi di sekolah mahasiswa juga menjelaskan maksud dan tujuanny. Program pembelajaran di lakukan dengan menggunakan WhatsApp Group agar orang tua 
murid juga mengetahui maksud dan tujuannya di buat Ruang belajar serta orang tua bisa mengawasi anaknya dalam belajar.

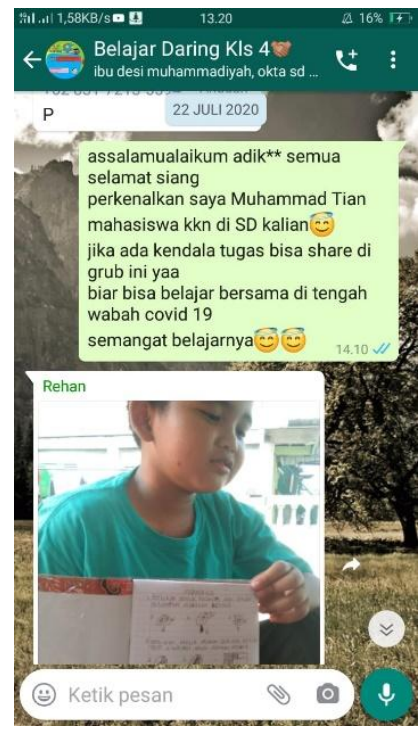

Gambar 7 Sosialisasi di WhatsApp Groub

\section{4). Pelaksanaan Program}

Terwujudnya ruang belajar daring melalui WhatsApp Group dengan adanya sesi diskusi dan sesi tanya jawab dari materi pelajaran yang belum dipahami oleh murid tetapi masih adanya kendala terkait adanya murid yang tidak mempunya HP sehingga solusinya dengan mendatangi ke rumah murid pada proses kegiatan pembelajaran untuk pendalaman materi dan materi pelajaran yang belum dipahami murid

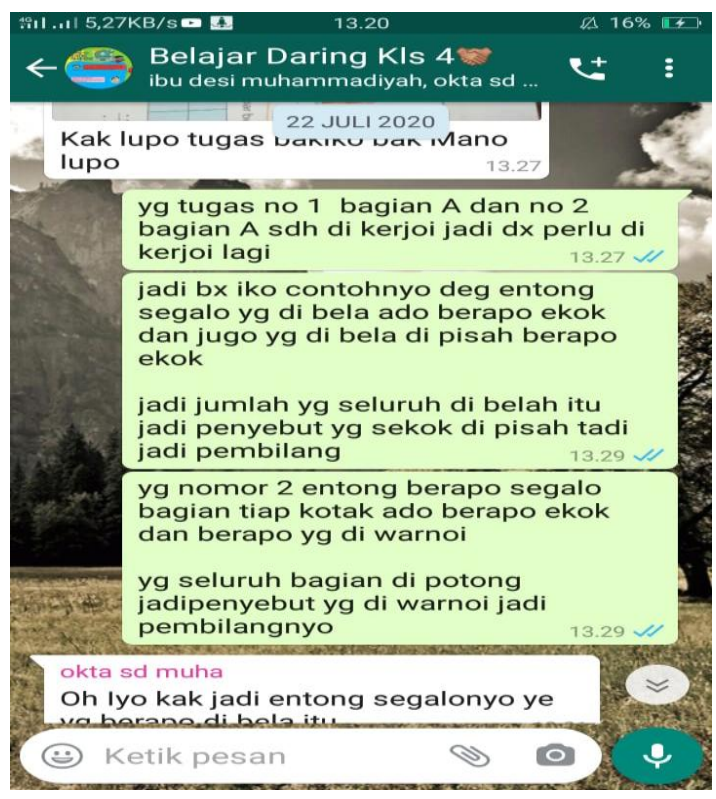

Gambar 8 Pelaksanaan Program 


\section{Tabel Analisis flow map}

Dari hasil evaluasi program di atas di dapatkan tabel analisisnya sebagai berikut

Tabel 1. Analisis flow map yang akan berjalan dari Hasil yang Dicapai

\begin{tabular}{|c|c|c|c|c|}
\hline No & Kegiatan & $\begin{array}{c}\text { Indikator } \\
\text { Keberhasilan }\end{array}$ & Hasil Kegiatan & Evaluasi \\
\hline 1. & $\begin{array}{l}\text { Penerapan } \\
\text { Daerah } \\
\text { Sasaran }\end{array}$ & $\begin{array}{l}\text { Mahasiswa } \\
\text { mendapatkan } \\
\text { gambaran terkait } \\
\text { daerah sasaran }\end{array}$ & $\begin{array}{l}\text { Bermitra di Sekolah dekat } \\
\text { tempat tinggal }\end{array}$ & $\begin{array}{l}\text { Terlaksana } \\
\quad(50 \%)\end{array}$ \\
\hline 2. & $\begin{array}{l}\text { Pembuatan } \\
\text { WhatsApp } \\
\text { Group }\end{array}$ & $\begin{array}{l}\text { Tersedianya ruang } \\
\text { belajar online }\end{array}$ & $\begin{array}{l}\text { Terciptanya ruang belajar } \\
\text { online terkait pembelajaran } \\
\text { daring }\end{array}$ & $\begin{array}{l}\text { Terlaksana } \\
\quad(50 \%)\end{array}$ \\
\hline 3. & Sosialisasi & $\begin{array}{l}\text { Memotivasi murid- } \\
\text { murid SD } \\
\text { Muhammadiyah } 22 \\
\text { Meranjat }\end{array}$ & $\begin{array}{l}\text { Termotivasinya murid-murid } \\
\text { SD Muhammadiyah } 22 \\
\text { Meranjat }\end{array}$ & $\begin{array}{l}\text { Terlaksana } \\
\quad(50 \%)\end{array}$ \\
\hline 4. & $\begin{array}{l}\text { Pelaksanaan } \\
\text { Program }\end{array}$ & $\begin{array}{l}\text { Membantu proses } \\
\text { pembelajaran daring }\end{array}$ & $\begin{array}{l}\text { Terwujudnya ruang belajar } \\
\text { daring melalui WhatsApp } \\
\text { Groupdengan adanya sesi } \\
\text { diskusi dan sesi tanya jawab } \\
\text { dari materi pelajaran yang } \\
\text { belum dipahami oleh murid } \\
\text { tetapi masih adanya kendala } \\
\text { terkait adanya murid yang tidak } \\
\text { mempunya HP sehingga } \\
\text { solusinya dengan mendatangi } \\
\text { ke rumah murid pada proses } \\
\text { kegiatan pembelajaran untuk } \\
\text { pendalaman materi dan materi } \\
\text { pelajaran yang belum dipahami } \\
\text { murid }\end{array}$ & $\begin{array}{l}\text { Terlaksana } \\
\quad(70 \%)\end{array}$ \\
\hline 5. & Laporan Akhir & $\begin{array}{l}\text { Hasil pencapaian } \\
\text { dari selama } \\
\text { pengambdian } \\
\text { dimasyarakat }\end{array}$ & $\begin{array}{l}\text { Solusi yang ditawarkan pada } \\
\text { proses pembelajaran dari untuk } \\
\text { meringankan beban orang tus } \\
\text { dengan adanya ruang belajar } \\
\text { online sehingga membantu } \\
\text { murid untuk memhami dan } \\
\text { mengulas kembali materi } \\
\text { pelajaran yang diberikan guru } \\
\text { terhadap materi pelajaran yang } \\
\text { belum dipahami murid }\end{array}$ & $\begin{array}{c}\text { Terlaksana } \\
70 \%\end{array}$ \\
\hline
\end{tabular}

\section{Potensi Keberlanjutan}

Keberlanjutan program RUANG BELAJAR ONLINE dapat didukung dengan adanya minat yang baik dari murid sehingga RUANG BELAJAR ONLINE ini bisa di lanjutkan,Keberlanjutan Programini jikanya nanti wabah penyakit covid-19 sudah hilang maka bisa di alihkan sebagai tempat Les online Bagi murid semua ataupun grub belajar 
secara online untuk digunakan sebagai ruang belajar bersama jika mempunyai tugas yang sulit di kerjakan sendiri

Keberlanjutan programRUANG BELAJAR ONLINE juga mampu mendukung beberapa aspek kehidupan, seperti :

1) Aspek Ekonomi murid tidak perlu datang ke sekolah dan bisa menabung uang jajan mereka untuk membeli kuota internet.

2) Aspek Kesehatan

Dengan pembelajaran online murid menghindari Resiko terdampak covid-19 dengan tidak bertemu langsung dengan orang lain.

\section{SIMPULAN}

Agar tetap menjaga dunia pendidikan bisa tetap berjalan dengan baik serta mendukung Pemerintah dalam mendukung Psysical distanting ditengah Pendemi Covid 19 sesuai intruksi presiden untuk tetap dirumah, belajar dirumah, bekerja dirumah, ibadah dirumah. Menteri Pendidikan dan Kebudayaan (Mendikbud) menindak lanjuti kebijakan tersebut melalui Surat Edaran (SE) Nomor, 4 Tahun 2020 Tentang Pelaksanaan Kebijakan Pendidikan Dalam Masa Darurat Penyebaran Covid-19, dalam hal ini poin 2 yang menyatakan, proses Belajar dari Rumah, untuk itu dalam menjalankan tugas sesaui arahan saya membuat grub ruang belajar online untuk membantu para orang tua dan murid dalam melaksanakan pembelajaran online dan tugas tugas yang di berikan oleh masing masing guru.Ruang belajar ini bertujuan untuk membantu murid dalam memahami materi pelajaran yang di berikan oleh guru serta memotivasi agar tetap belajar walaupun kondisi pembelajaran daring serta meringankan beban orang tua dslam mengontrol dan membantu siswa memahami materi pembelajaran.

\section{DAFTAR PUSTAKA}

Arsip Data sekolah SD Muhammadiyah 22 Meranjat (2019).

Arsip Monografi Desa Meranjat (2018).

Dewi,Wahyu.A.F.(2010). Dampak Covid-19 Terhadap Implementasi Pembelajaran Daring Di Sekolah Dasar. Ilmu Pendidikan. Vol.1(2). Hal:55-61.

Menteri Pendidikan. (2020). Surat Edaran Nomor 3 Tahun 2020 Tentang Pelaksanaan Pendidikan dalam Masa Darurat CoronaVirus (COVID-19). 
Nakayama M, Yamamoto H, \& S. R. (2007). The Impact of Learner Characterics on Learning Performance in Hybrid Courses among Japanese Students. Elektronic Journal E-Learning. Vol.5(3).1.

Pakpahan, r \& Fitriani, Y. (2020). Analisa Pemanfaatan Teknologi Informasi Dalam Pembelajaran Jarak Jauh Di Tengah Pandemi Virus Corona Covid-19. JISAMAR. Vol. 4(2).

Susilo,A,dkk (2020). Coronavirus Disease 2019: Tinjauan Literatur Terkini. Penyakit Dalam Indonesia. Vol. 7 (1).

Yurianto, Ahmad, Bambang Wibowo, K. P. (2020). Pedoman Pencegahan Dan Pengendalian Coronavirus Disease (Covid-19) (M. I. Listiana Azizah, Adistikah Aqmarina (ed.). 